\title{
EVALUASI KUALITAS INFORMASI PADA SISTEM INFORMASI NASKAH KUNO DINAS PERPUSTAKAAN DAN KEARSIPAN KOTA SALATIGA
}

\author{
Nalbraint Wattimena ${ }^{(1)}$ dan Augie D Manuputty ${ }^{\left({ }^{2}\right)}$ \\ ${ }^{1,2}$ Sistem Informasi, Fakultas Teknologi Informasi, Universitas Kristen Satya Wacana \\ ${ }^{1,2,}$ Jl. Blotongan, Sidorejo Lor, Sidorejo , Kota Salatiga, Jawa Tengah 50714 \\ E-mail :682016030@ @tudent.uksw.edu ${ }^{1)}$, augie.manuputty@uksw.edu ${ }^{2)}$
}

\begin{abstract}
ABSTRAK
Website Sikano merupakan website yang digunakan untuk pendataan buku naskah kuno, dokumentasi Sejarah dan peta Cagar Budaya oleh Dinas Perpustakaan dan Kearsipan Kota Salatiga. Naskah kuno yang merupakan salah satu warisan budaya Kota Salatiga diantara berbagai artefak lainnya, yang kandungan isinya mencerminkan berbagai pemikiran, pengetahuan, adat istiadat serta perilaku masyarakat masa lalu. Kualitas Informasi yang merupakan salah satu indikator utama keberhasilan penerapan sistem informasi. Dalam penelitian ini dilakukan evaluasi kualitas informasi Sistem Informasi Naskah Kuno menggunakan metode deskriptif kualitatif dengan 20 indikator, yaitu Accuracy, Consistency, Security, Timeliness, Completeness, Concise, Reliability, Accessibility Availability, Objectivity, Relevancy, Usability, Understandability, Amount of data, Believability, Navigation, Reputation, Useful, Efficiency dan Value-Added. Berdasarkan hasil analisis kualitas informasi Situs Website Sikano (Sistem Informasi Naskah Kuno) Kota Salatiga menggunakan 20 variabel dapat ditarik kesimpulan bahwa secara umum kualitas informasi situs web tersebut belum cukup baik terlihat pada indikator Accuracy, Consistency, Timeliness, Completeness, Reliability, Usability dan Amount of data yang belum memenuhi kualitas informasi pada web Sikano. Hal ini dikarenakan banyaknya kelengkapan data yang setelah ditelusuri masih sangat kurang, dan juga tampilan dari web tersebut yang tidak konsisten dan masih banyak adanya error. Setelah dilakukan analisis web dan wawancara dengan pihak pengelola web Sikano, menghasilkan banyak rekomendasi yang berkaitan dengan SDM pengelola web, Developer yang membangun web, re-design tampilan web, maintenance, penambahan jejak historis, hak akses admin, pengimputan rutin untuk admin. Rekomendasi yang dihasilkan berguna untuk peningkatan kebaruan dan kelengkapan data yang berpengaruh terhadap kualitas informasi Web Sikano Kota Salatiga.
\end{abstract}

Kata Kunci: Web Sikano, Sistem Informasi, Kualitas Informasi, Naskah Kuno, Deskriptif Kualitatif

\section{PENDAHULUAN}

Website Sikano merupakan website yang digunakan untuk pendataan buku naskah kuno, dokumentasi Sejarah dan peta Cagar Budaya oleh Dinas Perpustakaan dan Kearsipan Kota Salatiga. Website ini dibuat pada Tahun 2018, dimana dalam naskah kuno terdapat arsip statis. Arsip Statis merupakan arsip yang memiliki nilai guna kesejarahan yang telah habis retensinya, dan telah diversifikasi baik secara langsung maupun tidak langsung oleh Arsip Nasional Republik Indonesia atau Lembaga Kearsipan. Namun Website Sikano masih memiliki kekurangan yang terkait dengan kualitas informasi, seperti layout-nya sering error, warna tulisan yang di dalamnya berupa informasi sama dengan background sehingga menyulitkan pengguna untuk membaca . Oleh karena itu, perlu adanya evaluasi agar dapat mengidentifikasi kelemahan atau kekurangan, dan memberikan rekomendasi kepada Dinas Perpustakaan dan Kearsipan Kota Salatiga, karena keberadaan Website Sikano sangat penting untuk kemudahan akses informasi sejarah bagi masyarakat, selain itu juga menjadi media promosi keberadaan atau eksistensi dari sebuah instansi yaitu Dinas Perpustakaan dan Kearsipan Kota Salatiga. Dinas Perpustakaan dan Kearsipan Kota Salatiga merupakan sebuah instansi penyedia sumber informasi yang memanfaatkan peranan Teknologi Informasi dalam menjalankan proses bisnis perusahaan.

Evaluasi kualitas informasi berguna untuk mengukur informasi yang terdapat dalam sistem informasi dengan kualitas dapat memberikan nilai bagi pengguna sistem tertentu sehingga menghasilkan dengan karakteristik informasi yang sesuai dengan kebutuhan pengguna (Rukmiyati \& Budiartha, 2017). Dalam penelitian ini dilakukan evaluasi kualitas informasi Sistem Informasi Naskah Kuno menggunakan 20 indikator, yaitu Accuracy, Consistency, Security, Timeliness, Completeness, Concise, Reliability, Accessibility Availability, Objectivity, Relevancy, Usability, Understandability, Amount of data Believability, Navigation, Reputation, Useful, Efficiency dan Value-Added (Danamik \& Purwaningsih, 2017). Dengan indikator tersebut diharapkan dapat mengidentifikasi kekurangan dan memberikan rekomendasi kepada Dinas Perpustakaan dan Kearsipan Kota Salatiga agar senantiasa meningkatkan kualitas sistem dan kualitas informasi.

Penelitian mengenai Evaluasi Kualitas Informasi yang dijadikan sebagai penelitian terdahulu dan bahan 
referensi atau tinjauan pustaka dalam penelitian ini antara lain :

Penelitian berjudul Evaluasi Kualitas Informasi Situs Web Pemerintah Daerah Kabupaten Tolikara“. Penelitian ini menggunakan metode kualitatif deskriptif dan 20 dimensi untuk mengukur kualitas informasi Web, antara lain : Accuracy, Consistency, Security, Timeliness, Completeness, Concise, Reliability, Accessibility Availability, Objectivity, Relevancy, Usability, Understandability, Amount of data Believability, Navigation, Reputation, Useful, Efficiency dan ValueAdded. Penelitian ini menghasilkan beberapa kelemahan atau kekurangan, yaitu sebagian data dan informasi penting tentang daerah belum tersedia di Situs Web, beberapa menu dan sub menu belum berfungsi dengan baik dan keberadaan Situs Web belum cukup berguna bagi publik. Penelitian ini merekomendasikan perbaikan kualitas informasi secara menyeluruh agar Situs Web tersebut dapat memberikan manfaat bagi masyarakat dan juga memudahkan tugas-tugas Pemerintah Daerah Kabupaten Tolikara (Yikwa \& Sitokdana, 2020).

Penelitian berjudul "Evaluasi Kualitas Informasi Situs Web Pemerintah Kota Bitung".Penelitian ini berdasarkan 10 (sepuluh) indikator untuk mengukur kualitas informasi. Data dikumpulkan dengan melihat langsung pada situs web Pemerintah Kota Bitung disertai pengkajian terhadap jurnal-jurnal terkait. Penelitian ini menyimpulkan bahwa secara umum kualitas informasi Pemerintah Kota Bitung sudah cukup baik. Beberapa kekurangan yang ditemukan pada umumnya disebabkan oleh tautan yang error atau menuju ke halaman kosong sehingga diberikan rekomendasi untuk melakukan perbaikan dan peningkatan kualitas informasi (Kambey \& Sitokdana, 2020).

Penelitian berjudul "Analisis Kualitas Informasi Konten Website Repository Perpustakaan Universitas Airlangga".Penelitian ini menggunakan metode kuantitatif deskriptif. Data dikumpulkan menggunakan teknik purposive sampling sebanyak 100 responden yang merupakan pengguna dari situs repository Universitas Airlangga, baik internal (civitas akademik Universitas Airlangga) maupun eksternal. Penelitian ini menghasilkan penilaian pengguna terhadap ke empat dimensi kualitas informasi yang digunakan yaitu dimensi kualitas intrinsik informasi, dimensi konteks tual informasi, dimensi aksesibilitas informasi, dan dimensi penyajian informasi pada konten website repository Universitas Airlangga menunjukkan rata-rata skor yang seluruhnya masuk dalam kategori tinggi. Rata-rata pengguna telah menyetujui bahwa informasi dalam konten website repository Universitas Airlangga sudah memiliki keakuratan, sudah bersifat objektif, sudah memiliki kepercayaan, sudah memiliki reputasi yang baik, sudah relevan, memiliki nilai tambah, memiliki ketepatan waktu, reliabel, lengkap, memiliki jumlah yang cukup, mudah dalam proses pengaksesannya, sudah memiliki keamanan yang baik, sudah memiliki kemampuan interpretasi, mudah dipahami, memiliki penyajian yang ringkas, dan konsisten (Almira, 2018).

Penelitian dilakukan berjudul " Evaluasi Kualitas Sistem, Informasi dan Layanan Website Perguruan Tinggi sebagai Media Informasi Pemangku Kepentingan ".Penelitian ini bertujuan untuk membuktikan secara empiris keterkaitan antara pernyataan kesiapan pernyataan borang terkait dengan komunikasi, informasi dan sosialisasi terhadap hasil riset kepuasan pengguna sistem informasi sehingga bisa tercapai kesepahaman antara pernyataan standar pada nilai optimal dengan hasil penelitian ini nantinya. Metode yang digunakan dalam penelitian ini menggunakan survei. Sampel dalam penelitian ini adalah seluruh mahasiswa aktif program studi akuntansi Universitas Dian Nuswantoro. Regresi linier berganda sebagai alat analisis data. Hasil Penelitian menunjukkan bahwa kualitas informasi, kualitas sistem, kualitas layanan berpengaruh terhadap kepuasan pengguna website Program Studi Akuntansi Universitas Dian Nuswantoro (Setiawanta \& Oktafiyani, 2020).

Penelitian dilakukan oleh (Rizki, 2018) berjudul "Evaluasi Kualitas Kebergunaan, Kualitas Informasi, Dan Kualitas Interaksi Pelayanan Pada Website Dinas Pendidikan Menggunakan Metode Webqual Dan Importance Performance Analysis (Studi Kasus : Website Dinas Pendidikan Kabupaten Pasuruan)". Tujuan dilakukan evaluasi adalah untuk mengetahui kualitas usability, information quality, dan service interaction quality pada website Dinas Pendidikan Kab. Pasuruan. Sampel yang digunakan sebesar 100 responden dari populasi pengguna website, dengan teknik sampling simple random sampling. Pengumpulan data diperoleh dari penyebaran kuesioner kemudian dianalisis menggunakan statistik deskriptif dan perhitungan importance performance analysis. Hasil statistik deskriptif bahwa ketiga variabel tersebut masuk dalam kategori tinggi. Hasil nilai gap variabel usability didapatkan -0.35, information quality sebesar -0.32, dan service interaction quality sebesar -0.36 . Berdasarkan hal tersebut website belum memenuhi kualitas ideal yang diinginkan pengguna. Indikator yang perlu dilakukan perbaikan adalah desain warna web nyaman dilihat, jenis dan ukuran huruf mudah dibaca, warna background kontras dengan warna huruf, informasi up-to-date, informasi bermanfaat untuk pengguna, kemudahan berkomunikasi dengan organisasi (link ke SKPD), dan kecepatan respon dan memberikan tanggapan (Priyangga, Herlambang and Wardani, 2018).

\section{RUANG LINGKUP} berikut:

Ruang lingkup dalam penelitian ini adalah sebagai

1. Cakupan permasalahan dalam penelitian ini adalah website Sikano DINPERSIP merupakan website resmi yang menampung informasi kesejarahan dan kearsipan kota Salatiga sehingga harus dilakukan 
analisis terhadap kualitas informasi dari website tersebut.

2. Batasan penelitian ini adalah hanya fokus pada analisis kualitas informasi sehingga hanya menghasilkan rekomendasi kepada DINPERSIP dan tidak membahas perencanaan terkait kelanjutan dari rekomendasi tersebut.

3. Rencana penelitian akan dilakukan dengan melakukan analisis langsung pada tampilan dan infomasi pada website dan wawancara dengan pihak DINPERSIP kota Salatiga sehingga hasil akhir dari penelitian ini adalah dalam bentuk rekomendasi.

\section{BAHAN DAN METODE}

Bahan yang digunakan dalam penelitian ini berupa teori-teori pendukung dan parameter yang digunakan untuk mengukur kualitas informasi Web Sikano DINPERSIP Kota Salatiga.

\subsection{Sistem Informasi}

Sistem informasi merupakan kumpulan dari sub sistem yang terdiri secara fisik dan non fisik yang saling berhubungan satu sama lain untuk mengolah data menjadi informasi yang dibutuhkan oleh pengguna sistem (Prandhana, dkk, 2016). Menurut (Yuyut, 2018) Sistem informasi merupakan sekumpulan perangkat yang saling berhubungan dan terkait yang digunakan sebagai alat pengumpul, pemroses, penyimpan, dan pendistribusi data atau informasi yang berguna dalam pengambilan sebuah keputusan dan pengawasan dalam sebuah organisasi (Krisdiantoro, dkk, 2018).

\subsection{Kualitas Informasi}

Kualitas informasi merupakan suatu indikator dari keberhasilan sebuah sistem informasi. Sistem informasi yang dimaksud merupakan interaksi dari pengguna, data, proses, dan informasi untuk diproses dan menghasilkan output informasi yang diperlukan untuk mendukung sebuah instansi atau organisasi. Menurut Negash dalam Deri, kualitas informasi merupakan fungsi yang menyangkut nilai dari keluaran informasi yang dihasilkan oleh sistem (Yandi \& Septrizola, 2019). Menurut Jogiyanto dalam Yeur Yigwa, Kualitas informasi mengukur kualitas keluaran dari sistem informasi (Yikwa \& Sitokdana, 2020). Semakin tinggi kualitas informasi yang dihasilkan suatu sistem informasi, akan semakin meningkatkan kepuasan pengguna. Menurut DeLone dalam Prasojo, untuk menilai suatu kualitas informasi dapat menggunakan lima dimensi yaitu accuracy, timeliness, completeness, relevance, dan consistency (Prasojo \& Pratomo, 2015). Lebih rinci dan lengkap dikemukakan Knight \& Burn dalam Danamik, yaitu; 20 dimensi kualitas informasi yang dijadikan sebagai acuan dalam penelitian ini, yaitu Accuracy, Consistency, Security, Timeliness, Completeness, Concise, Reliability, Accessibility, Availability, Objectivity, Relevancy, Usability,
Understandability, Amount of data, Believability, Navigation, Reputation Useful, Efficiency dan ValueAdded (Danamik \& Purwaningsih, 2017).

\subsection{Naskah Kuno}

Naskah kuno merupakan warisan peradaban manusia sebagai akumulasi kehidupan masa lalu yang memiliki nilai informasi yang sangat berharga baik dari aspek sejarah maupun informasi yang termuat di dalam naskah tersebut (Mustopa, 2017). Naskah kuno sebagai salah satu warisan budaya dalam bentuk tertulis banyak mengandung informasi pengetahuan dan kearifan lokal masyarakat setempat pada masanya (Iswanto, 2018). Menurut Faizal Amin dalam Latiar, penulisan naskah kuno yaitu dalam berbagai aksara dan bahasa yang merefleksikan kemajuan anak bangsa dan terus hidup di tengah masyarakat (Latiar, 2018).

\subsection{Metode Penelitian}

Penelitian tentang Evaluasi Kualitas Informasi Sistem Informasi Naskah Kuno pada Dinas Perpustakaan Dan Kearsipan (DINPERSIP) Kota Salatiga menggunakan metode deskriptif kualitatif. Penelitian kualitatif merupakan penelitian yang fokus pada pertanyaan penelitian yang terkait dengan pertanyaan siapa, apa, dimana, dan bagaimana suatu peristiwa yang terjadi (Kim, dkk, 2017). Menurut Polit dalam Yuliani, deskriptif kualitatif adalah istilah yang digunakan dalam penelitian kualitatif untuk suatu kajian yang bersifat deskriptif (Yuliani, 2019). Dalam penelitian ini, data diambil dari jurnal dan Situs Web Sistem Informasi Naskah Kuno (Sikano.salatiga.go.id). Tahapan evaluasi kualitas informasi dimulai dengan mendeskripsikan dan menggambarkan tampilan isi konten Situs Web kemudian dilanjutkan dengan menganalisis kualitas informasi menggunakan 20 (dua puluh) dimensi kualitas informasi pada Tabel 1 di bawah ini (Danamik \& Purwaningsih, 2017).

Tabel 1. Dimensi Kualitas Informasi

\begin{tabular}{|l|l|l|}
\hline NO & $\begin{array}{l}\text { DIMENSI } \\
\text { KUALITAS } \\
\text { INFORMASI }\end{array}$ & \multicolumn{1}{c|}{ DEFINISI } \\
\hline 1 & Accuracy & Informasi bebas dari kesalahan \\
\hline 2 & Consistency & $\begin{array}{l}\text { Tidak bertentangan dengan } \\
\text { informasi sebelumnya }\end{array}$ \\
\hline 3 & Security & $\begin{array}{l}\text { Informasi tertentu dibatasi } \\
\text { dengan tepat }\end{array}$ \\
\hline 4 & Timeliness & Informasi tersedia tepat waktu \\
\hline 5 & Completeness & $\begin{array}{l}\text { Tidak ada bagian informasi } \\
\text { yang hilang }\end{array}$ \\
\hline 6 & Concise & $\begin{array}{l}\text { Informasi singkat padat dan } \\
\text { tepat }\end{array}$ \\
\hline 7 & Reliability & Informasi dapat diandalkan \\
\hline 8 & Accessibility & Informasi mudah didapatkan \\
\hline 9 & Availability & $\begin{array}{l}\text { Informasi dapat diakses setiap } \\
\text { saat }\end{array}$ \\
\hline 10 & Objectivity & $\begin{array}{l}\text { Informasi tidak bias dan tidak } \\
\text { berat sebelah }\end{array}$ \\
\hline
\end{tabular}




\begin{tabular}{|c|l|l|}
\hline 11 & Relevancy & $\begin{array}{l}\text { Bermanfaat dan dapat } \\
\text { digunakan untuk saat tertentu }\end{array}$ \\
\hline 12 & Usability & $\begin{array}{l}\text { Informasi jelas dan mudah } \\
\text { digunakan }\end{array}$ \\
\hline 13 & Understandability & $\begin{array}{l}\text { Informasi jelas tanpa } \\
\text { ambiguitas dan mudah } \\
\text { dipahami }\end{array}$ \\
\hline 14 & Amount of data & $\begin{array}{l}\text { Jumlah informasi yang tersedia } \\
\text { untuk diakses }\end{array}$ \\
\hline 15 & Believability & $\begin{array}{l}\text { Informasi dapat dipercaya dan } \\
\text { kredibel }\end{array}$ \\
\hline 16 & Navigation & $\begin{array}{l}\text { Informasi mudah ditemukan } \\
\text { dan dihubungkan ke informasi } \\
\text { lain }\end{array}$ \\
\hline 17 & Reputation & $\begin{array}{l}\text { Informasi menjadi rujukan } \\
\text { terpercaya }\end{array}$ \\
\hline 18 & Useful & $\begin{array}{l}\text { Informasi membantu } \\
\text { kelancaran tugas - tugas }\end{array}$ \\
\hline 19 & Efficiency & $\begin{array}{l}\text { Informasi memudahkan tugas - } \\
\text { tugas }\end{array}$ \\
\hline 20 & Value-Added & $\begin{array}{l}\text { Informasi memberikan manfaat } \\
\text { lebih }\end{array}$ \\
\hline
\end{tabular}

Tabel 1 merupakan definisi dari parameter kualitas informasi yang digunakan sebagai metode untuk mengukur seberapa baik kualitas informasi Web Sikano. Dari tabel diatas terdapat 20 parameter yang dibuat oleh Knight \& Burn sehingga dari tabel tersebut dapat menghasilkan rekomendasi-rekomendasi untuk meningkatkan kualitas informasi Web Sikano.

\section{PEMBAHASAN}

Pada bagian ini akan dilakukan analisis untuk mengukur 20 dimensi kualitas informasi web Sikano sehingga menghasilkan rekomendasi yang ditunjukkan kepada DINPERSIP Kota Salatiga.

\subsection{Deskripsi Tampilan dan Isi Web Sistem Informasi Naskah Kuno}

Pada bagian ini membahas tentang tampilan dan isi Web Sistem Informasi Naskah Kuno Kota Salatiga, yaitu www.Sikano.salatiga.go.id. Pengambilan gambar homepage web Sikano dilakukan pada tanggal 23 Februari 2021 seperti pada gambar 1.

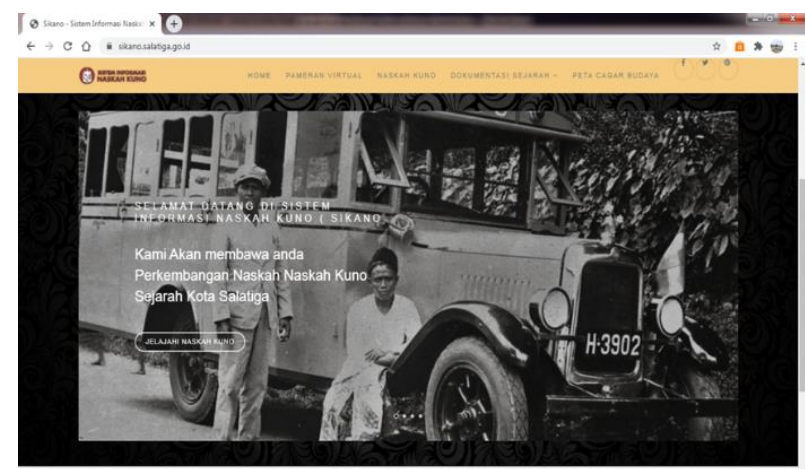

Gambar 1. Tampilan Depan Web Sistem Informasi Naskah Kuno
Pada bagian header (bagian atas) terdapat menu utama web, antara lain : Home, Pameran Virtual, Naskah Kuno, Dokumentasi Sejarah dan Peta Cagar Budaya. Masing - masing menu dapat dijelaskan sebagai berikut:

1. Home adalah halaman depan dari web sistem informasi naskah kuno dimana terdapat kata sambutan awal ketika web tersebut dijelajahi.

2. Pameran Virtual adalah penyajian informasi sejarah yang di dalamnya terdapat foto maupun video sejarah - sejarah di Salatiga.

3. Naskah Kuno adalah arsip yang dihasilkan karena memiliki nilai guna kesejarahan yang telah habis retensi, dan berketerangan dipermanenkan.

4. Dokumentasi Sejarah terdiri dari 3 sub-menu, yaitu (a) Dokumentasi Foto berisi foto-foto Kota Salatiga pada masa lalu. (b) Dokumentasi Video berisi video - video Kota Salatiga pada masa lalu. (c) Dokumentasi Cetak berisi surat kabar kota Salatiga pada masa lalu.

5. Peta Cagar Budaya merupakan 1 menu yang menunjukkan keberadaan cagar budaya yang ada di Kota Salatiga.

\subsection{Analisis Kualitas Informasi Situs Web Sikano Kota Salatiga}

Analisis kualitas informasi situs web Sikano.salatiga.go.id dilakukan dengan menganalisa setiap dimensi kualitas situs informasi. Analisis setiap dimensi dikerjakan dengan melihat langsung fakta lapangan pada situs web tersebut dengan didukung beberapa wawancara langsung dengan narasumber yang merupakan pihak pengelola web Sikano kota Salatiga. Adapun hasil analisis sebagai berikut :

1. Accuracy

Akurasi penyajian informasi sudah sangat tepat pada setiap menu dan halaman sehingga sudah terlihat cukup bagus, namun terlihat bahwa ketersediaan data dan informasi masih kurang update. Dapat dilihat dari setiap konten pada menu web yang tidak mengalami penambahan dan juta tidak didukung jejak historis pengimputan. Hal ini dikarenakan tidak adanya SDM (sumber daya manusia) yang bertanggung jawab untuk mengelola informasi pada web Sikano. Seperti yang disampaikan oleh Bapak Alwan Fauzan dari DINPERSIP Salatiga menjelaskan :

"Kendalanya ada di SDM itu sendiri (pengelola website). Jadi sebenarnya untuk data dan informasi kita ada dalam bentuk soft file yang kita simpan tetapi proses upload sendiri yang memakan waktu karena terkendala SDM yang belum ada untuk bertanggung jawab khusus untuk menangani konten web Sikano"

Berdasarkan hasil percakapan dengan Bapak Alwan Fauzan dari DINPERSIP Salatiga dapat dikatakan bahwa kendala yang terjadi ada pada SDM yang mengelola web Sikano. DINPERSIP sudah memiliki data dan informasi dalam bentuk soft file namun terkendala proses upload yang memakan waktu yang lama karena belum adanya 
SDM yang bertanggung jawab khusus untuk menangani konten web Sikano. Berdasarkan penjelasan diatas maka dapat dikatakan bahwa DINPERSIP Salatiga tidak memiliki SDM yang bertanggung jawab khusus untuk menjadi admin yang mengelola web Sikano.

2. Consistency

Informasi untuk setiap link sudah cukup baik namun konsistensi terhadap format setiap konten masih belum teratur. Dapat dilihat dari setiap konten informasi pada menu web memiliki format font dan warna yang berbeda-beda. Fakta lapangan pada web dapat dilihat pada menu dokumentasi sejarah dimana pada sub menu dokumentasi foto dan dokumentasi video memiliki perbedaan format dari segi tata letak, konten, juga jenis dan warna font yang berbeda. Seperti yang disampaikan oleh Bapak Alwan Fauzan dari DINPERSIP Salatiga menjelaskan :

"Hal ini dikarenakan admin dari web Sikano tidak memiliki hak akses untuk melakukan pergantian jenis dan warna font"

Seperti yang disampaikan oleh Bapak Alwan Fauzan dari DINPERSIP Salatiga dapat dikatakan bahwa perbedaan jenis dan warna font pada web Sikano dikarenakan admin dari web Sikano tidak memiliki hak akses untuk melakukan editing terkait hal-hal tersebut. Berdasarkan penjelasan diatas maka dapat dikatakan bahwa DINPERSIP tidak memiliki hak akses untuk melakukan editing terhadap jenis dan warna font konten terdapat di dalam web Sikano.

\section{Security}

Keamanan web Sikano bisa dikatakan baik karena sudah bersertifikat SSL (Secure Socket Layer) yang valid karena dapat dilihat dari link web yang sudah https namun belum diketahui terkait keamanan data pada web tersebut dikarenakan belum ada SDM yang ditunjuk khusus sebagai admin sehingga hak akses dari web tersebut belum terbatas.

\section{Timeliness}

Tidak ditemukan jejak historis pengimputan data dan informasi sehingga belum diketahui kebaruan dari data yang sudah ada. Dapat dilihat pada setiap konten informasi dari setiap menu web Sikano tidak tercantum penulis dan waktu pengimputan. Seperti yang disampaikan oleh Bapak Alwan Fauzan dari DINPERSIP Salatiga menjelaskan :

"Tidak ditemukannya histori pengimputan data atau informasi itu udah dari bawaan penyedia jasa (developer). Mungkin harus diberi histori di web tersebut mungkin ini sebagai masukan aja buat kita biar ke depannya harus diberi histori pengimputan data"

Dari hasil percakapan dengan Bapak Alwan Fauzan dari DINPERSIP Salatiga dapat dikatakan bahwa penyedia jasa web (developer) tidak membuat adanya histori pengimputan data sehingga hal ini bisa dijadikan masukan agar ke depannya web Sikano dibuatkan histori pengimputan data pada setiap konten yang terdapat di dalamnya. Berdasarkan penjelasan diatas maka dapat dikatakan bahwa Developer yang membangun web Sikano tidak menampilkan histori pengimputan data pada setiap konten di dalam web tersebut.

\section{Completeness}

Kelengkapan data sudah terpenuhi, tidak ada kekosongan pada setiap menu hal ini dapat dilihat dari setiap menu yang sudah disi dengan data dan informasi. Namun ada sebagian data yang tidak terlihat dikarenakan beberapa error dari web Sikano, hal ini dapat dilihat pada menu "cagar budaya" dan "sub menu dokumentasi cetak" pada menu "dokumentasi sejarah". Adapun data yang tidak terlihat bisa dibuka pada menu "peta cagar budaya" yang dapat menampilkan tulisan namun tidak menampilkan peta cagar budaya kota Salatiga. Error tersebut seperti yang disampaikan oleh Bapak Alwan Fauzan dari DINPERSIP Salatiga menjelaskan :

"Dikarenakan format yang berbeda dengan setiap gambar dan video yang di upload, dan juga bisa dikarenakan error pada server. Hal ini berhubungan dengan pihak ketiga yang ditunjuk sebagai developer yang membangun web Sikano, sehingga kami sebagai admin tidak bisa meruban font atau tampilan background dan lain-lain"

Seperti yang disampaikan oleh Bapak Alwan Fauzan dari DINPERSIP Salatiga dapat dikatakan bahwa perbedaan format pada setiap gambar dan video dalam web Sikano dikarenakan adanya error pada server web itu sendiri. Hal ini berhubungan dengan developer yang membangun web Sikano tidak memberikan hak akses kepada pihak DINPERSIP untuk melakukan perubahan font atau tampilan background dan lain-lain. Berdasarkan penjelasan diatas maka dapat dikatakan bahwa developer yang membangun web Sikano tidak memberikan hak akses kepada DINPERSIP untuk melakukan maintenance error dan perubahan font maupun tampilan background pada web tersebut.

6. Concise

Setiap halaman yang terisi data dan informasi sudah cukup baik karena dijelaskan secara singkat, padat dan jelas. Seperti yang disampaikan oleh Bapak Alwan Fauzan dari DINPERSIP Salatiga menjelaskan :

"Hal ini didukung dengan penelusuran kesejarahan dari DINPERSIP Kota Salatiga yang dilakukan dan sudah di akuisisi oleh DINPERSIP dengan sumber yang sedikit namun valid"

Berdasarkan hasil percakapan dengan Bapak Alwan Fauzan dari DINPERSIP Salatiga dapat dikatakan bahwa data informasi yang ada suda dijelaskan secara singkat, padat, dan jelas karena didukung dengan penelusuran kesejarahan dari DINPERSIP Kota Salatiga yang sudah di akuisisi sehingga walaupun sedikit namun data dan informasi tersebut valid. Berdasarkan penjelasan diatas maka dapat dikatakan bahwa dengan penelusuran kesejarahan dan akuisisi oleh DINPERSIP Salatiga sehingga data dan informasi yang terdapat di dalam web Sikano sudah valid. 


\section{Reliability}

Data dan informasi yang disajikan cukup bermanfaat namun belum dapat diandalkan dikarenakan data yang terdapat di dalam web Sikano belum up to date. Seperti yang disampaikan oleh Bapak Alwan Fauzan dari DINPERSIP Salatiga menjelaskan :

"Untuk manfaat dari informasi itu sendiri karena data dan informasi dalam bentuk soft file belum sepenuhnya di-input pada web Sikano. Ya karena itu tadi hal ini terkait belum adanya SDM yang ditunjuk khusus sebagai admin pengelola web. Jadi sebenarnya itu data-datanya ada tetapi untuk yang memperbaharui informasi di web Sikano itu yang belum ada jadi memang butuh waktu."

Dari hasil percakapan dengan Bapak Alwan Fauzan dari DINPERSIP Salatiga dapat dikatakan bahwa data dan informasi dalam web Sikano belum dapat diandalkan karena belum data dalam bentuk soft file belum sepenuhnya dimasukan di dalam web. Hal ini berkaitan dengan belum adanya SDM yang ditunjuk khusus sebagai admin pengelola web. Sehingga data dan informasi yang ada masih membutuhkan waktu untuk diperbaharui kedalam web Sikano. Berdasarkan penjelasan diatas maka dapat dikatakan bahwa data dan informasi di dalam web Sikano masih membutuhkan waktu untuk diperbaharui karena belum adanya SDM yang ditunjuk oleh DINPERSIP mengelola web tersebut.

\section{Accessibility}

Web Sikano dapat dengan mudah diakses pada link https://Sikano.salatiga.go.id dan juga memiliki konektivitas langsung dengan Web Dinas Perpustakaan dan Kearsipan Kota Salatiga. Dapat dilihat dari menu "Aplikasi dan Layanan Kami" pada link https://dinpersip.salatiga.go.id yang sudah disediakan link dari setiap web yang di wadahi oleh DINPERSIP Kota Salatiga yang salah satunya adalah Web Sikano.

\section{Availability}

Data dan informasi web Sikano dapat diakses menggunakan smartphone maupun PC/Laptop dimana saja dan kapan saja dengan membuka link https://Sikano.salatiga.go.id selama perangkat yang digunakan memiliki akses internet.

\section{Objectivity}

Data dan informasi yang disajikan pada situs web Sikano Seperti yang disampaikan oleh Bapak Alwan Fauzan dari DINPERSIP Salatiga menjelaskan:

"Data dan informasi tersebut merupakan data empiris atau data resmi yang sudah di akuisisi oleh DINPERSIP dengan penelusuran kesejarahan yang hati-hati karena berhubungan dengan sejarah pada Kota Salatiga sehingga data yang disajikan tidak bias dan tidak berat sebelah"

Berdasarkan hasil percakapan dengan Bapak Alwan Fauzan dari DINPERSIP Salatiga dapat dikatakan bahwa data dan informasi di dalam web Sikano tidak bias dan berat sebelah karena merupakan data empiris dan data resmi yang berhubungan dengan sejarah kota Salatiga dan sudah di akuisisi DINPERSIP dengan penelusuran kesejarahan yang hati-hati. Berdasarkan penjelasan diatas maka dapat dikatakan bahwa DINPERSIP tidak bias dan berat sebelah dalam mengelola data dan informasi di dalam web Sikano karena penelusuran kesejarahan yang dilakukan dengan hati-hati.

\section{Relevancy}

Data dan informasi yang disajikan cukup relevan karena data tersebut merupakan data resmi yang berhubungan dengan sejarah dan arsip Kota Salatiga.

\section{Usability}

Dari sisi kesejarahan, Seperti yang disampaikan oleh Bapak Alwan Fauzan dari DINPERSIP Salatiga menjelaskan :

"web Sikano dapat digunakan namun terkait kelengkapan data dan informasi yang tidak lengkap, web Sikano belum cukup bermanfaat. Kendalanya karena kita memang untuk penelusuran kesejarahan itu masih minim, budayawan di Salatiga pun juga tidak banyak jadi kita mendeskripsikan sesuatu itu meskipun sedikit yang penting valid"

Seperti yang disampaikan oleh Bapak Alwan Fauzan dari DINPERSIP Salatiga dapat dikatakan bahwa web Sikano dapat digunakan dalam sisi kesejarahan namun terkendala kelengkapan data dan informasi yang disajikan masih kurang sehingga web Sikano belum cukup bermanfaat. Hal ini disebabkan penelusuran kesejarahan yang masih minim dan sedikitnya budayawan di Kota Salatiga. Berdasarkan penjelasan diatas maka dapat dikatakan bahwa penelusuran kesejarahan yang dilakukan oleh DINPERSIP masih minim karena budayawan yang ada di kota Salatiga masih sedikit sehingga web Sikano masih belum lengkap untuk digunakan dalam sisi kesejarahan.

\section{Understandability}

Data dan informasi dari setiap konten sudah disajikan secara singkat, padat dan jelas sehingga data tersebut mudah dipahami. Hal ini didukung dengan penyajian data sejarah kota salatiga yang menggunakan bahasa yang baku dan sederhana.

\section{Amount of data}

Jumlah informasi yang tersedia masih sangat kurang karena dari setiap menu pada web Sikano belum memiliki kelengkapan data dan informasi yang up to date. Seperti yang disampaikan oleh Bapak Alwan Fauzan dari DINPERSIP Salatiga menjelaskan :

"Hal ini dikarenakan data dan informasi sejarah masih disimpan dalam bentuk soft file oleh DINPERSIP Kota Salatiga sehingga belum sepenuhnya terinput ke dalam web Sikano"

Dari hasil percakapan dengan Bapak Alwan Fauzan dari DINPERSIP Salatiga dapat dikatakan bahwa data dan informasi sejarah kota Salatiga masih tersimpan dalam bentuk soft file dan belum sepenuhnya di-input kedalam web Sikano. Berdasarkan penjelasan diatas maka dapat dikatakan bahwa DINPERSIP memiliki data banyak data yang belum di-input kedalam web Sikano karena data tersebut masih dalam bentuk soft file. 


\section{Believability}

Web Sikano merupakan web resmi yang diluncurkan oleh DINPERSIP dan memiliki data yang sudah terakuisisi melalui proses penelusuran kesejarahan sehingga data dan informasi yang disajikan oleh web tersebut dapat dipercaya.

\section{Navigation}

Navigasi web secara umum mudah diakses dengan cepat dan fungsi dari setiap menu web berjalan dengan baik. Dapat dilihat pada bagian header ikut turun saat pengguna melakukan scroll ke bawah sehingga tidak perlu melakukan scroll atas untuk mencari menu yang lain.

\section{Reputation}

Data dan informasi yang disajikan bisa dijadikan rujukan terpercaya karena data-data tersebut merupakan data resmi dari DINPERSIP Kota Salatiga.

\section{Useful}

Seperti yang disampaikan oleh Bapak Alwan Fauzan dari DINPERSIP Salatiga menjelaskan :

"Data dan informasi yang disajikan dapat digunakan karena menampung nilai kesejarahan dan kearsipan pada kota Salatiga sehingga dapat berguna untuk mencari informasi sejarah kota Salatiga atau Salatiga tempo dulu terlepas dari kekurangan dan kelengkapan data yang dimiliki oleh web Sikano"

Berdasarkan hasil percakapan dengan Bapak Alwan Fauzan dari DINPERSIP Salatiga dapat dikatakan bahwa untuk mencari informasi sejarah kota Salatiga tempo dulu, web Sikano dapat berguna karena web tersebut digunakan untuk menampun data dan informasi kesejarahan dan kearsipan pada kota Salatiga terlepas dari kekurangan dan kelengkapan yang dimilikinya. Berdasarkan penjelasan diatas maka dapat dikatakan bahwa web Sikano merupakan web resmi yang menampung informasi sejarah dan arsip kota Salatiga sehingga dapat digunakan sebagai acuan pencarian informasi kesejarahan kota Salatiga.

19. Efficiency

Terkait kelengkapan data dan informasi yang disajikan oleh web Sikano, web tersebut belum cukup memberikan informasi yang lengkap terkait sejarah dan arsip Kota Salatiga. Namun seperti yang disampaikan oleh Bapak Alwan Fauzan dari DINPERSIP Salatiga menjelaskan:

"Web tersebut bisa digunakan sebagai rujukan resmi sebagai dan acuan awal untuk mencari tau tentang informasi sejarah dan arsip Kota Salatiga sehingga bisa dikatakan efisien dalam memudahkan tugas-tugas yang berkaitan dengan sejarah dan arsip Kota Salatiga",

Dari hasil percakapan dengan Bapak Alwan Fauzan dari DINPERSIP Salatiga dapat dikatakan bahwa web Sikano dapat digunakan sebagai rujukan yang efisien dan resmi untuk mencari tau tentang informasi sejarah dan arsip kota Salatiga. Berdasarkan penjelasan diatas maka dapat dikatakan bahwa web Sikano memudahkan tugastugas yang berkaitan dengan informasi sejarah kota
Salatiga karena web tersebut merupakan web resmi dari DINPERSIP kota Salatiga.

\section{Value-added}

Data dan informasi yang disajikan pada web Sikano dapat memberikan nilai tambah dan manfaat terkait informasi sejarah dan arsip Kota Salatiga, namun belum sepenuhnya berguna. Hal ini terkait kelengkapan data dan informasi pada web Sikano yang masih sangat terbatas.

Dari Analisis 20 dimensi terkait kualitas informasi pada Web Sikano Kota Salatiga, menghasilkan beberapa rangkuman rekomendasi yang dapat menjadi masukan kepada pihak DINPERSIP Kota Salatiga, Sebagai berikut:

1) Penunjukan oleh atasan DINPERSIP Kota Salatiga kepada SDM/Pegawai yang khusus ditunjuk sebagai admin untuk menangani website terkait isi konten dan pengurusan dengan pihak ketiga.

2) Penunjukan pihak ketiga yang bertugas menangani hal-hal teknis yang berkaitan dengan web Sikano. Hal ini meliputi : Re-design terkait konsistensi format, jenis dan warna font setiap konten dan juga mengatasi kesamaan warna font dan background pada setiap konten yang di-input, Penanggulangan error, Penambahan jejak historis, Maintenance, Berkoordinasi dengan pihak DINPERSIP terkait hak akses dan pengimputan konten admin web Sikano.

3) Pendataan yang rutin oleh admin web Sikano

4) Meningkatkan kebaruan dan kelengkapan data dan informasi pada web Sikano

5) Menambahkan konektivitas web Sikano dengan media sosial DINPERSIP dan web-web dinas lain yang terdapat dalam lingkungan Pemkot Salatiga.

\section{KESIMPULAN}

Berdasarkan hasil analisis kualitas informasi Situs Web Sikano (Sistem Informasi Naskah Kuno) Kota Salatiga menggunakan 20 variable yaitu : Accuracy, Consistency, Security, Timeliness, Completeness, Concise, Reliability, Accessibility Availability, Objectivity, Relevancy, Usability, Understandability, Amount of data Believability, Navigation, Reputation, Useful, Efficiency dan Value-Added dapat ditarik kesimpulan bahwa secara umum kualitas informasi situs web tersebut belum cukup baik. Hal ini dikarenakan banyaknya kelengkapan data yang setelah ditelusuri masih sangat kurang, dan juga tampilan dari web tersebut yang tidak konsisten dan masih banyak adanya error. Kurangnya kelengkapan data dapat dilihat dari banyaknya data dalam bentuk soft file yang belum di input kedalam web, tampilan web yang tidak konsisten dapat dilihat pada menu dokumentasi sejarah dimana pada sub menu dokumentasi foto dan dokumentasi video memiliki perbedaan format dari segi tata letak, konten, juga jenis dan warna font yang berbeda, dan adanya error pada tampilan web dapat dilihat pada menu "cagar 
budaya" dan "sub menu dokumentasi cetak" pada menu "dokumentasi sejarah. Setelah dilakukan analisis web dan wawancara dengan pihak pengelola web Sikano, menghasilkan banyak rekomendasi yang berkaitan dengan SDM pengelola web, Developer yang membangun web, re-design tampilan web, maintenance, penambahan jejak historis, hak akses admin, pengimputan rutin untuk admin. Rekomendasi yang dihasilkan berguna untuk peningkatan kebaruan dan kelengkapan data yang berpengaruh terhadap kualitas informasi Web Sikano Kota Salatiga.

\section{SARAN}

Saran ke depan untuk peneliti selanjutnya untuk melakukan tahapan perencanaan dari rekomendasirekomendasi yang dihasilkan dari penelitian ini sehingga hasil analisis dapat lanjutkan ke tahap penyelesaian masalah dengan menggunakan metode-metode yang berhubungan dengan rekomendasi-rekomendasi tersebut.

\section{DAFTAR PUSTAKA}

Danamik, M. P. and Purwaningsih, E. H. 2017 'EGoverment dan Aplikasinya di Linkungan Pemerintah Daerah (Studi Kasu Kualitas Informasi Website Kabupaten Bengkalis Propinsi Riau)', pp. 151-164.

Iswanto, A. 2018 'Kajian Teologi Penciptaan Alam dan Manusia Nurhata Revitalisasi Kearifan Lokal Naskah-naskah Primbon Koleksi Masyarakat Indramayu', 8(2), p. 43.

Kambey, D. J. F. and Sitokdana, M. 2020 'Evaluasi Kualitas Informasi Situs Web Pemerintah Kota Bitung', Seminar Nasional Teknologi Komputer ..., (SAINTEKS), pp. 7-12. Available at: http://seminar-

id.com/prosiding/index.php/sainteks/article/view/ 396.

Kim, H., Sefcik, J. S. and Bradway, C. 2017 'Characteristics of Qualitative Descriptive Studies: A Systematic Review', Journal of Career and Technical Education, 21(1), pp. 5170. doi: 10.1002/nur.21768.Characteristics.

Krisdiantoro, Y., Subekti, I. and Prihatiningtias, Y. W. 2018 'Pengaruh Kualitas Sistem Dan Kualitas Informasi Terhadap Manfaat Bersih Dengan Intensitas Penggunaan Sebagai Variabel Mediasi', Jurnal Akuntansi Aktual, 5(2), pp. 149-167. doi: 10.17977/um004v5i22018p149.

Latiar, H. 2018 'Preservasi Naskah Kuno Sebagai Upaya Pelestarian Budaya Bangsa', Al-Kuttab: Jurnal Perpustakaan dan Informasi, 5(1), p. 67. doi: 10.24952/ktb.v5i1.827.

Mustopa. 2017 'Mushaf Kuno Lombok: Telaah Aspek Penulisan dan Teksnya', Suhuf, 10(1), pp. 1-24. doi: 10.22548/shf.v10i1.215.

Prandhana, A. R., Nurhayati, N. and Haumatusadiah, E.
2016 'Pengaruh Kualitas Layanan, Kualitas Sistem dan Kualitas Informasi terhadap Tingkat Kepuasan Pengguna (Survey Pada Karyawan Pengguna Aplikasi Sia Pada Bank Umum Syariah Di Kota Bandung)', Prosiding Akuntansi, 2(2), pp. 926-933.

Prasojo, L. H. and Pratomo, D. 2015 'Pengaruh kualitas informasi, kualitas sistem, dan kualitas layanan aplikasi Rail Ticket System (RTS) terhadap kepuasan pengguna sistem ( Studi Kasus pada PT - Kereta Api Indonesia ( Persero ) DAOP 2 Bandung', e-Proceeding of Management, 2(1), p. 235. Available at: http://repository.unpas.ac.id/id/eprint/1646\%0A.

Priyangga, R. W., Herlambang, A. D. and Wardani, N. H. 2018 'Evaluasi Kualitas Kebergunaan, Kualitas Informasi , Dan Kualitas Interaksi Pelayanan Pada Website Dinas Pendidikan Menggunakan Metode Webqual Dan Importance Performance Analysis ( Studi Kasus: Website Dinas Pendidikan Kabupaten Pasuruan )', Jurnal Pengembangan Teknologi Informasi dan Ilmu KOmputer, 2(10), pp. 3729-3737.

Rukmiyati, N. M. S. and Budiartha, I. K. 2017 'Pengaruh Kualitas Sistem Informasi, Kualitas Informasi, Dan Perceived Usefulness Terhadap Kepuasan Pengguna Akhir Software Akuntansi', 1, p. 21.

Setiawanta, Y. and Oktafiyani, M. 2020 'Evaluasi Kualitas Sistem, Informasi dan Layanan Website Perguruan Tinggi sebagai Media Informasi Pemangku Kepentingan', Jurnal Bisnis dan Ekonomi, 27(2), pp. 135-144. Available at: https://unisbank.ac.id/ojs/index.php/fe3/article/vie w/8197.

Yandi, D. R. and Septrizola, W. (2019) 'Terhadap Minat Beli Ulang Pengguna E-Commerce Situs Blibli . Com dengan Kepuasan Sebagai Variabel Intervening pada Masyarakat Kota Padang', 01, pp. 67-77.

Yikwa, Y. and Sitokdana, M. 2020 'Evaluasi Kualitas Informasi Situs Web Pemerintah Daerah Kabupaten Tolikara', Seminat Nasional Informatika (SEMNASIF).

Yuliani, W. 2019 'Metode Penelitian Deskriptif Kualitatif Dalam Perspektif Bimbingan dan Konseling,, Quanta, 3(1), pp. 9-19. doi: 10.22460/q.v1i1p1-10.497. 